\title{
Usefulness of Evaluation of Nuclear Color by Visible-Microscopic Spectroscopy for Objective Differentiation between Non-Cancer and Cancer Cells Prepared Using Liquid-Based Cytology
}

\author{
Haruhiko Yoshioka1, Keita Hoshiai ${ }^{1}$, Toshiya Nakamura ${ }^{2,3}$, Kayo Horie ${ }^{1}$, Kiyotada Washiya ${ }^{1}$ and Jun Watanabe ${ }^{1,3}$ \\ ${ }^{1}$ Department of Pathologic Analysis, Division of Medical Life Sciences, Hirosaki University Graduate School of Health Sciences, Japan \\ ${ }^{2}$ Department of Biomedical Sciences, Division of Medical Life Sciences, Hirosaki University Graduate School of Health Sciences, Japan \\ ${ }^{3}$ Research Center for Biomedical Sciences, Hirosaki University Graduate School of Health Sciences, Japan
}

\begin{abstract}
Objective: The aims of this study were to investigate the usefulness of color evaluation of the nuclear region using visible-microscopic spectroscopy (Vis-MS) and to clarify whether it can serve as an index to distinguish cancer cells in liquid-based cytology (LBC). Vis-MS is a spectral analysis technique widely used for absorption and fluorometric analyses in the analytical chemistry field. Vis-MS has been applied to histological diagnosis, but only a few studies on its application to cytology have been performed, and no investigations have been performed for LBC, which is expected to become widely used in Japan. Study design: Using culture cell lines of non-cancer cells and cancer cells, transmittance at $530 \mathrm{~nm}$ (maximum absorption wavelength of eosin), $580 \mathrm{~nm}$ (hematoxylin), and 630 $\mathrm{nm}$ (light green), and $530 \mathrm{~nm} / 580 \mathrm{~nm}$ and $630 \mathrm{~nm} / 580 \mathrm{~nm}$ transmittance ratios were analyzed.

Results: Two variances of the transmittance at $580 \mathrm{~nm}$ and $630 \mathrm{~nm} / 580 \mathrm{~nm}$ transmittance ratio were finally extracted as effective items after applying forward and backward variance selection and investigation of multicollinearity. The odds ratios of $580 \mathrm{~nm}$ transmittance and $630 \mathrm{~nm} / 580 \mathrm{~nm}$ transmittance ratio were 0.48 and 0.72 , respectively. The cancer cell discrimination predictive value determined using the logistic regression equation was $98.0 \%$, being favorable.

Conclusion: It was suggested that Vis-MS is useful to evaluate the color of the nuclear region and serves as a cancer cell discrimination index for LBC. We are planning to apply Vis-MS to clinical materials and develop nuclear color evaluation using Vis-MS into an objective index for cases in which cancer cell judgment is difficult.
\end{abstract}

\section{Keywords:}

Liquid-based cytology; Visible-microscopic spectroscopy; Papanicolaou stain; Logistic regression

\section{Introduction}

Visible-microscopic spectroscopy (Vis-MS) is a spectral analysis technique widely used for absorption [1] and fluorometric [2] analyses in the analytical chemistry field. The solvent of most samples of VisMS is an aqueous solution, and only a few studies with materials of histological diagnosis [3,4] and cytology [5] have been performed. Regarding the staining method used for Vis-MS, studies on Feulgen's reaction and staining with hematoxylin alone [6-9] have been performed, but only a few studies have been performed for unstained samples and Papanicolaou staining [10].

Liquid-based cytology ( $\mathrm{LBC}$ ) is expected to become widely used in Japan. Using a residual LBC sample remaining in a vial, additional tests (immunocytochemistry and gene analysis) can be performed, increasing the diagnostic accuracy [11-16]. However, increased staining intensity of the nuclear chromatin and nuclear size reduction in LBC samples may make cancer cell judgment difficult in well-differentiated adenocarcinoma lacking atypia [17-22].

Conventionally, the color density of the nuclear region of cancer cells has been an important diagnostic factor. Generally, however, color evaluation of this region is subjective and varies widely among observers. Major characteristics of Vis-MS are: 1) It represents the color of the nuclear region by dispersing and redifferentiating it as continuous wavelengths in the visible light range (400-700 $\mathrm{nm}$ ), and 2) it expresses the color density of the nuclear region as the transmittance of each continuous wavelength. Using Vis-MS, color evaluation of the nuclear region of cancer cells is expected to become more detailed and objective, improving the precision of discrimination between cancer and non-cancer cells.

The objectives of this study were to investigate the usefulness of color evaluation of Papanicolaou-stained nuclear regions using VisMS and to clarify whether it can serve as a cancer cell discrimination index for LBC. The goal for the future is to apply evaluation of the color of the nuclear region using Vis-MS to clinical cases in which cancer cell discrimination is difficult and to establish an objective index for cancer cell judgment using Vis-MS.

\section{Material and Methods}

\section{Cultured cells used for LBC}

For non-cancer-derived cells, 2 cell lines: human skin fibroblasts (NHDF) [23] and African green monkey kidney-derived cells (COS-7) [24], were used. For cancer cells, 4 cell lines: human lung cancer cells

*Corresponding author: Haruhiko Yoshioka, Hirosaki University Graduate School of Health Sciences, 66-1 Honcho, Hirosaki, Aomori 036-8564, Japan, Tel: +81 17239 5972; Fax: +81 17239 5972; E-mail: yoshioka@cc.hirosaki-u. ac.jp

Received December 26, 2014; Accepted January 29, 2015; Published January 31,2015

Citation: Yoshioka H, Hoshiai K, Nakamura T, Horie K, Washiya K et al. (2015) Usefulness of Evaluation of Nuclear Color by Visible-Microscopic Spectroscopy for Objective Differentiation between Non-Cancer and Cancer Cells Prepared Using Liquid-Based Cytology. J Cytol Histol 6: 308. doi:10.4172/2157-7099.1000308

Copyright: (c) 2015 Yoshioka H, et al. This is an open-access article distributed under the terms of the Creative Commons Attribution License, which permits unrestricted use, distribution, and reproduction in any medium, provided the original author and source are credited. 
Citation: Yoshioka H, Hoshiai K, Nakamura T, Horie K, Washiya K et al. (2015) Usefulness of Evaluation of Nuclear Color by Visible-Microscopic Spectroscopy for Objective Differentiation between Non-Cancer and Cancer Cells Prepared Using Liquid-Based Cytology. J Cytol Histol 6: 308. doi:10.4172/2157-7099.1000308

Page 2 of 6

(A549) [25], human breast cancer cells (MCF-7) [26], human colon adenocarcinoma cells (LS-180) [27], and human gastric cancer cells (KATOIII) [28], were used.

One milliliter of trypsin-treated culture fluid containing cultured cells $\left(1 \times 10^{6} / \mathrm{mL}\right)$ of each cell line was combined with $9 \mathrm{~mL}$ of $\mathrm{LBC}$ solution, ThinPrep PreservCyt Solution (ThinPrep, HOLOGIC), and the $10-\mathrm{mL}$ suspension was left to stand overnight.

Sample processing for UV-MS was as follows: Each suspension was distributed into cups ( $5 \mathrm{~mL}$ per cup) and directly smeared on slide glasses by centrifugation (Cyto-Tec Cytocentrifuge Model CF-127, Sakura, Japan) at 1,500 rpm for 2 minutes, followed by wet fixation with $95 \%$ ethanol for 30 minutes and standard Papanicolaou staining.

\section{Lambert-Beer law in Vis-MS}

Light absorption and absorption analysis using Vis-MS in the analytical chemistry field were applied to LBC. Data were collected following the principle of light absorption in analytical chemistry, the Lambert-Beer law.

The principle of absorbance measurement is measurement of the amount of light absorbed when monochromatic light passes through a sample. A sample at a concentration of $c(c m M)$ is added to an absorption cell. When the intensity of monochromatic light with an intensity of $I_{0}$ becomes $I$ after passing through the cell with an optical path length, $l, \frac{I}{I_{0}}$ represents transmittance and is designated as $T$. When this is presented as a percentage (\%), it is termed percent transmittance and designated as $T \% .-\log \frac{I}{I_{0}}$ is termed absorbance and designated as A. Accordingly, absorbance is formulated as:

$$
A=-\log T=-\log \frac{I}{I_{0}}=\varepsilon c l .
$$

$\varepsilon$ represents the extinction coefficient. Absorbance is proportionate to the passage distance of the light and the concentration of the solution (Lambert-Beer law).

Excluding a few exceptions, absorbance is measured for the total concentration of different chemical species because of the additive property of absorbance. The absorbance of a sample containing $n$ active absorbance values is presented by the equation below:

$$
A=-\log \frac{I}{I_{0}}=d l \sum_{i=1}^{n} \varepsilon_{i} c_{i} .
$$

Using multifunctional software for spectroscopy (Ocean Photonics, Japan), percent transmittance, $T \%$, was measured on the assumption that this equation is established.

\section{Vis-MS apparatus}

Vis-MS was performed using a Vis-MS apparatus developed by Hirosaki University Graduate School of Health Sciences, and the light source and spectroscope were defined [10]. For the intermediate filter of the light source of Vis-MS, a Vis-mirror module was set, through which only visible light $(400-700 \mathrm{~nm})$ can be selected from the broad continuous wavelength range of the light source lamp. Since a highperformance cold mirror is used for the Vis-mirror module, unnecessary heating can be completely inhibited, resulting in an extremely low level of stray light. The nuclear measurement area to acquire a spectrum was set at $166.4 \mu^{2}(12.9 \times 12.9 \mu \mathrm{m})$ in all measured cells. This area was mostly fitted into the nucleus. To confirm the absence of a difference in the nuclear area/measured area ratio between non-cancer and cancer cells, the area of the analyzed nucleus was measured in 10 cells, and the area ratio was compared between 20 non-cancer and 40 cancer cells (60 cells in total).

\section{Acquired image and wavelength data, and correction wavelength}

Vis images on Vis-MS were acquired using image acquisition software (Basico, CLARO, Japan) in Bitmap format. Generally, a color perceived by humans is presented as the maximum absorption wavelength of the color. The color perceived by humans is complementary colors of the maximum absorption wavelength. The color of Papanicolaou staining includes 530 [29], 560-580 [6$8,29]$, and $630 \mathrm{~nm} \mathrm{[30]} \mathrm{as} \mathrm{the} \mathrm{maximum} \mathrm{absorption} \mathrm{wavelengths} \mathrm{of}$ eosin, aluminum-mordanted hematoxylin, and light green SF dyes, respectively.

In a Papanicolaou-stained nuclear region, the total absorbance of these dyes (additive property of absorbance) is measured (equation 2.2).

\section{Data correction with $580 \mathrm{~nm}$ transmittance}

Generally, a color is presented as the maximum absorption wavelength of the color, or numerically presented using a spectrophotometer. However, in samples with multiple staining, such as those stained with Papanicolaou and hematoxylin-eosin (HE), the spectral absorbance has to be interpreted as absorbance of the total concentration of the dyes based on the additive property of absorbance (equation 2.2) [31]. In this study, setting the baseline at the absorbance of the maximum absorption wavelength of hematoxylin dye, $580 \mathrm{~nm}$, the ratio of the absorbance of the maximum absorption wavelength of each dye to the baseline was used as a corrected value for standardization, that is, the intensities of eosin and light green dyes were presented as the $530 \mathrm{~nm} / 580 \mathrm{~nm}$ and $630 \mathrm{~nm} / 580 \mathrm{~nm}$ transmittance ratios, respectively. A high $530 \mathrm{~nm} / 580 \mathrm{~nm}$ transmittance ratio indicates that the transmittance at $530 \mathrm{~nm}$ (purplish-red) relative to that at $580 \mathrm{~nm}$ (purple) is high, that is, the color tone is bright purplish-red, and a high $630 \mathrm{~nm} / 580 \mathrm{~nm}$ transmittance ratio indicates that the transmittance at $630 \mathrm{~nm}$ (blue/green) relative to that at $580 \mathrm{~nm}$ (purple) is high, that is, the color tone is bright blue/green. The use of these corrected values is advantageous in that the additive property of absorbance in multiple stained samples can be corrected, which enables expression of the color tone. Nuclear dye was measured in 50 cells of each cell line, 300 cells in total: 100 non-cancer-derived cells and 200 cancer cells.

In the data on this nuclear color analysis: 1) transmittance represents brightness of the absorption wavelength, and 2) a corrected value represents color tone of the wavelength.

\section{Statistical analysis}

The means and standard deviations of transmittance at wavelengths of 530,580, and $630 \mathrm{~nm}$ in non-cancer and cancer cells were calculated. Similarly, the means and standard deviations of $530 \mathrm{~nm} / 560 \mathrm{~nm}$ and $630 \mathrm{~nm} / 580 \mathrm{~nm}$ transmittance ratios were calculated. After testing the normality of distribution of each data set in the non-cancer and cancer cells using the Shapiro-Wilk test, the significance of differences between the non-cancer and cancer cells was tested as follows:

When the distribution was not normal, the Mann-Whitney $U$ test was employed. When the distribution was normal, equality of variances was tested in each sample using Levene's test. The t-test and Welch's test were used to test the significance of differences when the variance was equal and unequal, respectively. These statistical analyses 
Citation: Yoshioka H, Hoshiai K, Nakamura T, Horie K, Washiya K et al. (2015) Usefulness of Evaluation of Nuclear Color by Visible-Microscopic Spectroscopy for Objective Differentiation between Non-Cancer and Cancer Cells Prepared Using Liquid-Based Cytology. J Cytol Histol 6: 308. doi:10.4172/2157-7099.1000308

Page 3 of 6

were performed using statistical analysis software, SPSS 16.0j.

Factors influencing predictive cancer cell judgment were analyzed using binomial logistic regression analysis [32]. A logistic regression model is a method to analyze the relationship between objective and explanatory variances, regarding a binary variance as an objective variance. For example, a binary variance represents data assigning $D=0$ to a non-cancer cell and $\mathrm{D}=1$ to a cancer cell. In the logistic regression model, the probability that this binary variance is $1(D=1)$ is designated as $\mathrm{p}$. Probability $\mathrm{p}$ is explained with explanatory variances, such as the $260 \mathrm{~nm}$ and $280 \mathrm{~nm}$ transmittance values, in this model. In a binominal logistic regression model, when the number of explanatory variances is $\mathrm{k}[\mathrm{x}=(\mathrm{x} 1, \mathrm{x} 2, \ldots \mathrm{xk})]$ for logit of probability $\mathrm{p}$, these are related by the following functions:

$$
\begin{aligned}
& \log \frac{p(x)}{1-p(x)}=\mathrm{a}+\hat{a}_{1} x_{1}+\hat{a}_{2} x_{2}+\cdots+\hat{a}_{k} x_{k} \\
& p(x)=\frac{1}{1+\exp \left(-\left(\hat{a}+\hat{a}_{1} x_{1}+\hat{a}_{2} x_{2}+\cdots+\hat{a}_{k} x_{k}\right)\right)}
\end{aligned}
$$

The ratio of occurrence probability, $\mathrm{p}(\mathrm{x})$, to non-occurrence probability, $1-\mathrm{p}(\mathrm{x})$, is termed the odds, and its natural logarithm is termed the logit of probability $\mathrm{p}(\mathrm{x})$. Therefore, the logistic regression model is intended to explain the logit of probability of an event with explanatory variances.

Regarding multicollinearity that destabilizes the logistic regression model, variances with a Spearman's rank correlation coefficient $r>0.8$ between explanatory variances were excluded. In addition, univariate logistic regression analysis was performed in consideration of the relationship of a cancer cell $(\mathrm{D}=1)$ with each variance. For the selection of explanatory variances, forward and backward variance selection using the likelihood ratio test was employed. Goodness of fit of the logistic regression equation was analyzed using the likelihood ratio test. In the residual test, when the absolute value was greater than the studentized residual by 2 , the value was regarded as an outlier. These statistical analyses were performed using statistical analysis software, Ekuseru-Toukei 2012 (Social Survey Research Information Co., Ltd.).

\section{Results}

\section{Papanicolaou-stained non-cancer-derived and cancer cells}

Figure 1 shows Papanicolaou-stained non-cancer-derived and cancer cells and the measured areas. The cell appearance pattern was scattered with poor connectivity in all non-cancer-derived cells: NHDF (Figure 1a) and COS-7 (Figure 1b), and cancer cells: LS-180 (Figure 1c), Kato-III (Figure 1d), MCF-7 (Figure 1e), and A549 (Figure 1f). The cell shape was round/oval. The nucleus:cytoplasm ratio (N/C ratio) was high (about $80-90 \%$ ). The nucleus was round/oval, and 1 or 2 small nucleoli were noted. Regarding the color of the nucleus of each cell, the intensity of purple was stronger in cancer cells than in non-cancerderived cells. Regarding the color tone to distinguish non-cancer and cancer cells, it is difficult to express the cytological findings with purplish-red and bluish-purple tones, other than purple.

\section{Vis-MS spectral analysis of non-cancer-derived and cancer cells}

The nuclear area measured in the images of Papanicolaou-stained cells and the ratio of the nuclear area to the Vis-MS measurement area (nuclear area/measurement area ratio) are compared between non-cancer and cancer cells in Table 1 . The ratios were $1.13 \pm 0.22$ and $1.10 \pm 0.21$ in non-cancer and cancer cells, respectively, showing no significant difference. The nuclear area was slightly larger than the measurement area in both non-cancer and cancer cells.

The results of Vis-MS spectral analysis are shown in Table 2. The values corrected with the transmittance ratio of non-cancer and cancer cells are shown in Figure 2. The $580 \mathrm{~nm}$ transmittance was significantly lower (high intensity of purple) in cancer cells $(27.4 \pm 6.7 \%)$ than in non-cancer cells $(51.5 \pm 9.3 \%)(\mathrm{p}<0.001)$. The $530 \mathrm{~nm} / 580 \mathrm{~nm}$ transmittance ratio was significantly higher (pale red) in cancer cells $(109.1 \pm 6.5 \%)$ than in non-cancer cells $(95.2 \pm 4.2 \%)(\mathrm{p}<0.001)$, and the $630 \mathrm{~nm} / 580 \mathrm{~nm}$ transmittance ratio was significantly lower (dark blue/green) in cancer cells $(45.7 \pm 7.7 \%)$ than in non-cancer cells $(64.2$ $\pm 8.6 \%)(\mathrm{p}<0.001)$.

Prior to binomial logistic regression analysis, a variance with a 0.8 or greater correlation coefficient of covariance-variance matrix between explanatory variances is deleted because it has multicollinearity. In the analysis of Spearman's rank correlation coefficient (Table 3), the correlation coefficient between the $580 \mathrm{~nm}$ transmittance and the 530

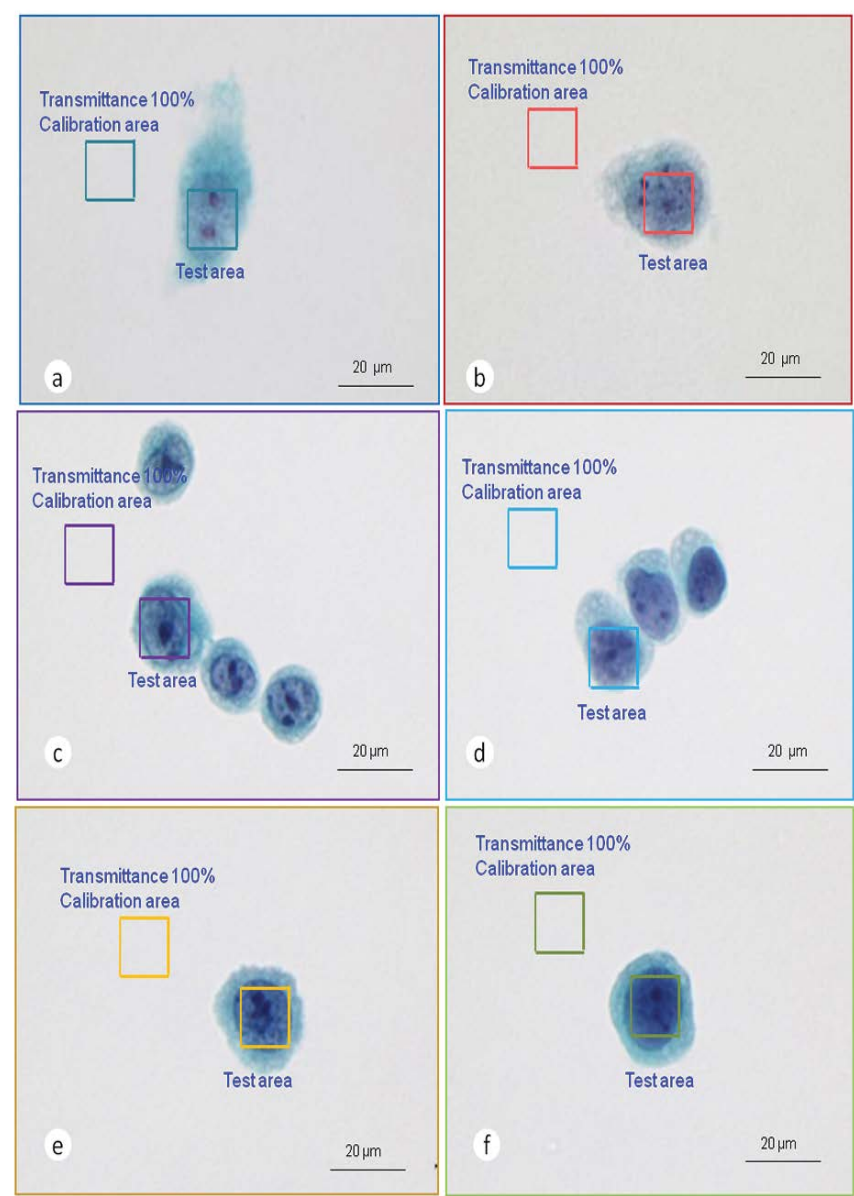

Figure 1: Papanicolaou-stained cells by LBC Non-cancer cells: NHDF (a), COS-7 (b); cancer cells: LS-180 (c), MCF-7 (d), A549 (e), Kato-III (f).

The color of the nucleus of each cell, the intensity of purple was stronger in cancer cells than in non-cancer-derived cells. Regarding the color tone to distinguish non-cancer and cancer cells, it is difficult to express the cytological findings with purplish-red and bluish-purple tones, other than purple. Non-cancer-derived and cancer cells were similar with regard to many of the points in the above cellular findings. 
Citation: Yoshioka H, Hoshiai K, Nakamura T, Horie K, Washiya K et al. (2015) Usefulness of Evaluation of Nuclear Color by Visible-Microscopic Spectroscopy for Objective Differentiation between Non-Cancer and Cancer Cells Prepared Using Liquid-Based Cytology. J Cytol Histol 6: 308. doi:10.4172/2157-7099.1000308

Page 4 of 6

\begin{tabular}{|c|c|c|c|}
\hline & $\begin{array}{c}\text { Non-cancer } \\
\text { cells }(\mathbf{n = 2 0})\end{array}$ & $\begin{array}{c}\text { Cancer cells } \\
(\mathbf{n = 4 0 )}\end{array}$ & p-value* \\
\hline Nuclear area $\left(\boldsymbol{\mu m}^{\mathbf{2}}\right)$ & $188.3 \pm 36.6$ & $183.8 \pm 35.6$ & 0.461 \\
\hline $\begin{array}{c}\text { Nuclear area/ } \\
\text { measurement area ratio }\end{array}$ & $1.13 \pm 0.22$ & $1.10 \pm 0.21$ & 0.461 \\
\hline \multicolumn{2}{|c|}{ *Mann-Whitney U test } \\
\hline
\end{tabular}

Table 1: Comparison of the ratio of nuclear area/measurement area between non-cancer and cancer cells.

\begin{tabular}{|c|c|c|c|}
\hline \multirow[b]{2}{*}{ Wavelength (nm) } & Non-cancer cells $(n=100)$ & $\begin{array}{l}\text { Cancer cells } \\
(n=200)\end{array}$ & \multirow[t]{2}{*}{ P-value } \\
\hline & \multicolumn{2}{|c|}{ Transmittance (mean \pm SD $\%$ ) } & \\
\hline 530 & $49.3 \pm 10.3$ & $29.9 \pm 7.1$ & \multirow{3}{*}{$<0.001^{*}$} \\
\hline 580 & $51.5 \pm 9.3$ & $27.4 \pm 6.7$ & \\
\hline 640 & $33.3 \pm 8.6$ & $12.8 \pm 4.7$ & \\
\hline Correction & \multicolumn{2}{|c|}{ Division value (mean \pm SD $\%$ ) } & \multirow{3}{*}{$<0.001^{*}$} \\
\hline $530 / 580$ ratio & $95.2 \pm 4.2$ & $109.1 \pm 6.5$ & \\
\hline $630 / 580$ ratio & $64.2 \pm 8.6$ & $45.7 \pm 7.7$ & \\
\hline
\end{tabular}

Table 2: Comparison of the transmittance measured using the Vis-MS and the division of $560 \mathrm{~nm}$ values between non-cancer and cancer cells.

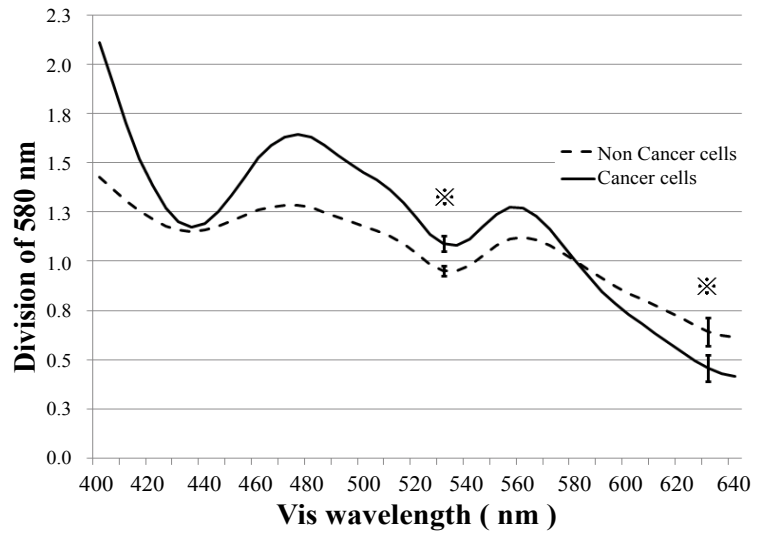

※ $\mathrm{p}<0.001 \quad$ Mann Whitney- U test

Figure 2: Comparison of the division of $580 \mathrm{~nm}$ transmittance ratio on Papanicolaou-stained cultured cells $(n=300)$

Non-cancer cells: NHDF, COS-7; cancer cells: LS-180, MCF-7, A549, Kato-III. The $530 \mathrm{~nm} / 580 \mathrm{~nm}$ transmittance ratio was significantly higher (pale red) in cancer cells $(109.1 \pm 6.5 \%)$ than in non-cancer cells $(95.2 \pm 4.2 \%)(p<0.001)$, and the $630 \mathrm{~nm} / 580 \mathrm{~nm}$ transmittance ratio was significantly lower (dark blue/green) in cancer cells $(45.7 \pm 7.7 \%)$ than in non-cancer cells $(64.2 \pm$ $8.6 \%)(p<0.001)$.

$\mathrm{nm} / 580 \mathrm{~nm}$ transmittance ratio was $\mathrm{r}=-0.66(\mathrm{p}<0.01)$, that between the $580 \mathrm{~nm}$ transmittance and the $630 \mathrm{~nm} / 580 \mathrm{~nm}$ transmittance ratio was $\mathrm{r}=0.79(\mathrm{p}<0.01)$, and that between the $530 \mathrm{~nm} / 580 \mathrm{~nm}$ and $530 \mathrm{~nm} / 580$ $\mathrm{nm}$ transmittance ratios was $\mathrm{r}=-0.51(\mathrm{p}<0.01)$, being $\mathrm{r}<0.8$, clarifying that measurements between the variances are useful for the analysis. The discrimination predictive value of each variance is determined, and a variance with a low value is excluded. The results of univariate logistic regression analysis are shown in Table 4 . On the likelihood ratio test, the p-values of $580 \mathrm{~nm}$ transmittance, $530 \mathrm{~nm} / 580 \mathrm{~nm}$ transmittance ratio, and $630 \mathrm{~nm} / 580 \mathrm{~nm}$ transmittance ratio were less than 0.001 , and the discrimination predictive values were also high (95.7, 92.0, and 88.7, respectively), showing that these were useful as explanatory variances for this analysis.

Accordingly, the following 3 conditions were candidates for binomial logistic regression analysis of Vis-MS analysis to distinguish non-cancer and cancer cells: 1) The $580 \mathrm{~nm}$ transmittance and the 530 $\mathrm{nm} / 580 \mathrm{~nm}$ transmittance ratio are regarded as explanatory variances, 2) the $580 \mathrm{~nm}$ transmittance and the $630 \mathrm{~nm} / 580 \mathrm{~nm}$ transmittance ratio are regarded as explanatory variances, and 3) the $530 \mathrm{~nm} / 580 \mathrm{~nm}$ and $630 \mathrm{~nm} / 580 \mathrm{~nm}$ transmittance ratios are regarded as explanatory variances, and analyses were performed using analysis software. Analysis with Condition 1) was discontinued during the analysis using software due to an error: 'inverse matrix of Fisher information matrix is absent on the 47th repetitive estimation'. In Condition 3), all values were corrected with the $580 \mathrm{~nm}$ transmittance. Since we wanted to include transmittance expressing brightness and intensity of color in the variances, this condition was excluded. As a result of the above process, finally, binomial logistic regression analysis with the $580 \mathrm{~nm}$ transmittance and the $630 \mathrm{~nm} / 580 \mathrm{~nm}$ transmittance ratio as explanatory variances was performed.

The results of binomial logistic regression analysis are shown in Table 5. The $580 \mathrm{~nm}$ transmittance $(\mathrm{p}<0.001)$ and the $630 \mathrm{~nm} / 580 \mathrm{~nm}$ transmittance ratio $(\mathrm{p}<0.001)$ were selected as factors influencing the predictive judgment of cancer cells. The likelihood ratio test result of the regression equation was $\mathrm{P}<0.001$, showing a favorable fit. The odds ratios of the $580 \mathrm{~nm}$ transmittance and the $630 \mathrm{~nm} / 580 \mathrm{~nm}$ transmittance ratio were 0.48 (95\% confidence interval: $0.34-0.67)$ and 0.72 (95\% confidence interval: $0.59-0.87$ ), respectively. None of these $95 \%$ confidence intervals was 1 , and the discrimination predictive value of the predicted and measured value was $98.0 \%$. On the residual test, outliers with a studentized residual exceeding 2 accounted for only $0.3 \%$. The logistic function is shown below, and it was clarified that the cancer cell probability ( $\mathrm{p}$ ) of the measured cell can be determined using the following equation.

$$
p(x)=\frac{1}{1+\exp \left(-41.19+0.73 x_{1}+0.33 x_{2}\right)} x_{1}=[580 \mathrm{~nm}] x_{2}=[630 / 580 \%]
$$

\section{Discussion}

In terms of the characteristics of LBC, the cell distribution is homogeneous, the nuclear size is slightly reduced, and the nucleus is intensely stained. These characteristics tend to make cancer cell judgment difficult in well-differentiated adenocarcinoma lacking atypia [16-21]. According to the cellular findings in our study, non-cancerderived and cancer cells were similar with regard to many of the points, and differentiation of them was difficult. Discrimination between non-cancer and cancer cells used to be difficult with LBC procedure (Figure 1). In conventional methods, it is difficult similarly. However, using Vis-MS, redifferentiation of the color of the nuclear region and quantification of the density became possible, allowing more accurate and objective judgments. As a result, a logistic regression model (R square: 0.92 ) to calculate the probability of a cell being cancerous could be obtained. Thus, we investigated the usefulness of evaluating the color of the nuclear region using Vis-MS to discriminate cancer and noncancer cells. In nuclear color evaluation using Vis-MS, light that passed

\begin{tabular}{|c|c|c|c|c|c|}
\hline & $\mathbf{5 3 0} \mathbf{n m}$ & $\mathbf{5 8 0} \mathbf{n m}$ & $\mathbf{6 3 0} \mathbf{n m}$ & $\begin{array}{c}\mathbf{5 3 0 / 5 8 0} \\
\text { rate }\end{array}$ & $\begin{array}{c}\mathbf{6 3 0 / 5 8 0} \\
\text { rate }\end{array}$ \\
\hline $\mathbf{5 3 0} \mathbf{n m}$ & 1.0 & 0.98 & 0.95 & -0.53 & 0.78 \\
\hline $\mathbf{5 8 0} \mathbf{n m}$ & 0.98 & 1.0 & 0.97 & -0.66 & 0.79 \\
\hline $\mathbf{6 3 0} \mathbf{n m}$ & 0.95 & 0.97 & 1.0 & -0.63 & 0.91 \\
\hline $\mathbf{5 3 0 / 5 8 0}$ ratio & -0.53 & -0.66 & -0.63 & 1.0 & -0.51 \\
\hline $\mathbf{6 3 0 / 5 8 0}$ ratio & 0.78 & 0.79 & 0.91 & -0.51 & 1.0 \\
\hline \multicolumn{7}{|r}{} \\
\hline
\end{tabular}

Table 3: Estimated Covariance Matrix of the Estimated Coefficients in Table 2. 
Citation: Yoshioka H, Hoshiai K, Nakamura T, Horie K, Washiya K et al. (2015) Usefulness of Evaluation of Nuclear Color by Visible-Microscopic Spectroscopy for Objective Differentiation between Non-Cancer and Cancer Cells Prepared Using Liquid-Based Cytology. J Cytol Histol 6: 308. doi:10.4172/2157-7099.1000308

Page 5 of 6

\begin{tabular}{|c|c|c|c|c|c|c|c|c|c|c|}
\hline & \multirow{2}{*}{$\begin{array}{l}\text { Accuracy } \\
\text { of the } \\
\text { regression } \\
\text { equation ( } R \\
\text { square) }\end{array}$} & \multirow{2}{*}{$\begin{array}{l}\text { Likelihood } \\
\text { ratio } \\
\text { regression } \\
\text { equation }\end{array}$} & \multirow{2}{*}{$\begin{array}{l}\text { Partial } \\
\text { regression } \\
\text { coefficient }\end{array}$} & \multirow{2}{*}{$\begin{array}{c}\text { Standardized } \\
\text { partial } \\
\text { regression } \\
\text { coefficient }\end{array}$} & \multirow{2}{*}{$\begin{array}{l}\text { Test of } \\
\text { significance } \\
\text { of partial } \\
\text { regression } \\
\text { coefficient }\end{array}$} & \multirow{2}{*}{ Odds ratio } & \multicolumn{2}{|c|}{$\begin{array}{c}95 \% \text { confidence interval of } \\
\text { odds ratio }\end{array}$} & \multirow{2}{*}{$\begin{array}{l}\text { Discrimination } \\
\text { predictive } \\
\text { value (\%) }\end{array}$} & \multirow{2}{*}{$\begin{array}{l}\text { Residual } \\
\text { test (\%) }\end{array}$} \\
\hline & & & & & & & Lower limit & Upper limit & & \\
\hline $530 \mathrm{~nm}$ & 0.62 & $<0.01$ & -0.37 & -4.56 & $<0.01$ & 0.70 & 0.63 & 0.76 & 88.7 & 0.3 \\
\hline $580 \mathrm{~nm}$ & 0.85 & $<0.01$ & -0.64 & -8.78 & $<0.01$ & 0.53 & 0.42 & 0.66 & 95.7 & 0.3 \\
\hline $630 \mathrm{~nm}$ & 0.88 & $<0.01$ & -0.95 & -10.85 & $<0.01$ & 0.39 & 0.26 & 0.58 & 96.0 & 0.3 \\
\hline $530 / 580$ rate & 0.66 & $<0.01$ & 0.52 & 4.51 & $<0.01$ & 1.68 & 1.47 & 1.91 & 92.0 & 0.7 \\
\hline $630 / 580$ rate & 0.54 & $<0.01$ & -0.24 & -2.82 & $<0.01$ & 0.79 & 0.75 & 0.83 & 88.7 & 0.7 \\
\hline
\end{tabular}

Table 4: Univariate logistic regression analysis.

\begin{tabular}{|c|c|c|c|c|c|c|}
\hline & \multirow{2}{*}{$\begin{array}{l}\text { Partial regression } \\
\text { coefficient }\end{array}$} & \multirow{2}{*}{$\begin{array}{c}\text { Standardized } \\
\text { partial regression } \\
\text { coefficient }\end{array}$} & \multirow{2}{*}{$\begin{array}{l}\text { Test of significance } \\
\text { of partial regression } \\
\text { coefficient }\end{array}$} & \multirow{2}{*}{ Odds ratio } & \multicolumn{2}{|c|}{$95 \%$ confidence interval of odds ratic } \\
\hline & & & & & Lower limit & Lower limit \\
\hline $580 \mathrm{~nm}$ & -0.73 & -10.03 & $<0.001$ & 0.48 & 0.34 & 0.67 \\
\hline $630 / 580$ rate & -0.34 & -3.98 & $<0.001$ & 0.72 & 0.59 & 0.87 \\
\hline Constant & 48.19 & & & & & \\
\hline \multicolumn{7}{|c|}{$\begin{array}{l}\text { Accuracy of the regression equation ( } R \text { square): } 0.92 \\
\text { Significance of regression equation (likelihood ratio test): }<0.001\end{array}$} \\
\hline \multicolumn{7}{|c|}{ Discrimination predictive value: $98.0 \%$} \\
\hline \multicolumn{7}{|c|}{ Residual test (rate of values with a studentized residual exceeding 2 ): $0.3 \%$} \\
\hline
\end{tabular}

Table 5: Binomial logistic regression analysis of $580 \mathrm{~nm}$ value and $630 / 580 \mathrm{~nm}$ value ratio.

through the nucleus was split, and the spectrum of transmittance at each visible light wavelength was employed, which led to objective data being obtained. Biesterfeld et al. [9] acquired nuclear spectra of uterine cervical squamous cell carcinoma cells using Feulgen's reaction, simple hematoxylin staining, and Papanicolaou staining, but the DNA level could not be measured in simple hematoxylin- and Papanicolaoustained cells. Some studies reported that Feulgen's reaction was useful for cancer cell judgment [5-10], but such judgment based on Papanicolaou-stained nuclear color analysis has not been reported.

In our analytical data, using not only transmittance but also the ratio of transmittance at each wavelength to that at $580 \mathrm{~nm}$, which is a corrected variance representing the color ratio, it was clarified that dark green compared with purple and pale red compared with purple are useful to discriminate cancer cells. The interpretation of these color ratios was also applicable for cancer cell judgment of cells containing pale chromatin (pale purple). However, judgment of the color ratio by the human eye may be difficult.

The interpretation of nuclear color depends on the property of the staining dye. In Papanicolaou-stained nuclei, basic components (such as DNA) are stained with hematoxylin, and acidic components (such as proteins) are stained with eosin and a light green dye. Upon staining with a single dye, transmittance represents the brightness based on the maximum absorption of the dye. Measurements at the maximum absorption wavelengths, of 580 and $530 \mathrm{~nm}$, are sufficient for simple staining with hematoxylin and eosin, respectively. However, Papanicolaou staining involves multiple staining, and the nuclear spectrum represents the total concentration of nuclear dyes due to the additive property of absorbance (equation 2.2). Specifically, Papanicolaou staining involves multiple staining with hematoxylin, OG-G, and EA-50. Therefore, the nuclear spectrum on Papanicolaou staining reflects the total absorbance of these dyes due to the additive property. Thus, correction of the transmittance of the maximum absorption wavelength of each dye in the measured spectrum is necessary because of the influences of the other dyes. We determined the ratio of the maximum absorption wavelength of each dye to that $(580 \mathrm{~nm})$ of hematoxylin dye as a corrected value and employed it as a variance. This is a unique characteristic of this study not noted in previous studies. For eosin and light green dyes, 530/580 and 630/580 $\mathrm{nm}$ ratios were employed as corrected values, respectively. A high $530 / 580 \mathrm{~nm}$ ratio indicates an intense purplish/red tone compared with purple, the color of hematoxylin. A high $630 / 580 \mathrm{~nm}$ ratio indicates intense bluish-purple. Color tone can be expressed using these standardized corrected values, which is an advantage of this method.

When these findings of the spectral wavelengths were converted to the color of the nuclear region, it was clarified that, to predict cancer cells, it is useful to pay attention to a high intensity of purple (low 560 $\mathrm{nm}$ transmittance, $\mathrm{p}<0.001)$, an intense green color compared with purple (low $630 \mathrm{~nm} / 580 \mathrm{~nm}$ transmittance ratio, $\mathrm{p}<0.001$ ), and a pale red color compared with purple (high $530 \mathrm{~nm} / 580 \mathrm{~nm}$ transmittance ratio, $\mathrm{p}<0.001)$. As an objective method to identify an unknown cell as a cancer cell or not, binomial logistic regression analysis of the 580 $\mathrm{nm}$ transmittance and the $630 \mathrm{~nm} / 580 \mathrm{~nm}$ transmittance ratio on VisMS was useful (equation: $\mathrm{R}^{2}: 0.92$, discrimination predictive value: $98 \%$ $(\mathrm{p}<0.001))$ (Table 5).

These findings suggest that evaluation of the color of the nuclear region using Vis-MS is useful to judge cancer cells on LBC. This method is objective and accurate, and suggested to be useful for cancer cell judgment of cultured cell lines. This analytical method employing Vis-MS applicable for LBC is expected to become widely used. We are planning to apply this nuclear color evaluation method employing VisMS to clinical materials and establish an objective index to identify cancer cells in cases that are difficult to judge.

\section{Acknowledgments}

This study was supported by a grant for Hirosaki University Institutional Research (2010-2012). The authors are grateful to Drs. Koichi Ito, Kosuke Kasai, and Manabu Nakano of Hirosaki University Graduate School of Health Sciences for preparing cell lines. The authors are grateful to Drs. Tatsusuke Sato and Terumasa Takamatu of Claro, Inc., for technical advice and expertise of Vis-MS.

\section{References}

1. Cheung MC, Evans JG, McKenna B, Ehrlich DJ (2011) Deep ultraviolet mapping of intracellular protein and nucleic acid in femtograms per pixel. Cytometry A 79: 920-932.

2. Fujii K, Yamaguchi M, Ohyama N, Mukai k (2002) Development of support systems for pathology using spectral transmittance. Proc SPIE 4648: 1516-1523. 
Citation: Yoshioka H, Hoshiai K, Nakamura T, Horie K, Washiya K et al. (2015) Usefulness of Evaluation of Nuclear Color by Visible-Microscopic Spectroscopy for Objective Differentiation between Non-Cancer and Cancer Cells Prepared Using Liquid-Based Cytology. J Cytol Histol 6: 308. doi:10.4172/2157-7099.1000308

Page 6 of 6

3. Garini Y, Young IT, McNamara G (2006) Spectral imaging: principles and applications. Cytometry A 69: 735-747.

4. Richards-Kortum R, Sevick-Muraca E (1996) Quantitative optical spectroscopy for tissue diagnosis. Annu Rev Phys Chem 47: 555-606.

5. Schubert JM, Bird B, Papamarkakis K, Miloš Miljković M, Bedrossian K, et al. (2010) Spectral cytopathology of cervical samples: detecting cellular abnormalities in cytologically normal cells. Lab Invest 90: 1068-1077.

6. Bettinger C, Zimmermann HW (1991) New investigations on hematoxylin, hematein, and hematein-aluminium complexes. I. Spectroscopic and physicochemical properties of hematoxylin and hematein. Histochemistry 95: 279-288.

7. Gurley AM, Hidvegi DF, Bacus JW, Bacus SS (1990) Comparison of the Papanicolaou and Feulgen staining methods for DNA quantification by image analysis. Cytometry 11: 468-474.

8. Feng C, Shuzhen C, Libo Z (2007) New Abnormal Cervical Cell Detection Method of Multi-Spectral Pap Smears. WUJNS 12: 476-480.

9. Biesterfeld S, Beckers S, Del Carmen Villa Cadenas M, Schramm M (2011) Feulgen staining remains the gold standard for precise DNA image cytometry. Anticancer Res 31: 53-58.

10. Yoshioka H, Hoshiai K, Nakamura T, Tatsusuke S, Washiya K, et al. (2014) Usefulness of Ultraviolet-Microscopic Spectroscopy on Unstained Cells by Liquid-Based Cytology for Objective Differentiation between Non-cancer from Cancer cells. Hirosaki Med J 65: 82-94.

11. Watanabe J, Nishimura Y, Tsunoda S, Kawaguchi M, Okayasu I, et al. (2009) Liquid-Based Preparation for Endometrial Cytology - Usefulness for Predicting the Prognosis of Endometrial Carcinoma Preoperatively. Cancer (Cance Cytopathol) 117: 254-263.

12. Kim GE, Kweon SS, Lee JS, Lee JH, Nam JH, et al. (2012) Quantitative assessment of DNA methylation for the detection of cervical and endometrial adenocarcinomas in liquid-based cytology specimens. Anal Quant Cytopatho Histpathol 34: 195-203.

13. Spathis A, Kottaridi C, Georgoulakis J, Foukas P, Panayiotides I, et al. (2011) Cell cycle analysis of colorectal brushings collected in liquid-based cytology. Anal Quant Cytol Histol 33: 29-35.

14. Malapelle U, de Rosa N, Rocco D, Bellevicine C, Crispino C, et al. (2012) EGFR and KRAS mutations detection on lung cancer liquid-based cytology: a pilot study. J Clin Pathol 65: 87-91.

15. Vocaturo A, Novelli F, Benevolo M, Piperno G, Marandino F, et al. (2006) Chromogenic in situ hybridization to detect HER-2/neu gene amplification in histological and ThinPrep-processed breast cancer fine-needle aspirates: a sensitive and practical method in the trastuzumab era. Oncologist 11: 878-886.

16. Sartelet H, Lagonotte E, Lorenzato M, Duval I, Lechki C, et al. (2005) Comparison of liquid based cytology and histology for the evaluation of HER-2 status using immunostaining and $\mathrm{CISH}$ in breast carcinoma. J Clin Pathol 58 864-871.
17. Kuramoto H, Iwami Y, Sugimoto N, Kato C, Sugahara T, et al. (2012) Application of a new liquid-based procedure (TACAS) for the screening of cervical cancer: a preliminary study. Acta Cytol 56: 74-79.

18. Nance KV (2007) Evolution of Pap testing at a community hospital: a ten year experience. Diagn Cytopathol 35: 148-153.

19. Akamatsu S, Himeji Y, Ikuta N, Shimagaki N, Maruoka H, et al. (2008) Satisfactoriness and disease detection in the screening specimens of cervical cancer - comparison between liquid-based and conventional methods. Jpn J Clin Cytol 47: 420-424

20. Hutchinson $M L$, Isenstein LM, Goodman A, Hurley AA, Douglass $K L$, et al. (1994) Homogeneous sampling accounts for the increased diagnostic accuracy using the ThinPrep Processor. Am J Clin Pathol 101: 215-219.

21. Lee KR, Ashfaq R, Birdsong GG, Corkill ME, Mclntosh KM, et al. (1997) Comparison of conventional Papanicolaou smears and a fluid-based, thin-layer system for cervical cancer screening. Obstet Gynecol 90: 278-284.

22. Hatch KD, Sheets E, Kennedy A, Ferris DG, Darragh T, et al. (2004) Multicenter direct to vial evaluation of a liquid-based pap test. J Low Genit Tract Dis 8: 308-312.

23. Nakamura T, Takagaki K, Shibata S, Tanaka k, Higuchi T, et al. (1995) Hyaluronic-acid-deficient extracellular matrix induced by addition of 4-methylumbelliferone to the medium of cultured human skin fibroblasts. Biochem Biophys Res Commun 208: 470-475.

24. Okabe K, Inada N, Gota C, Harada Y, Funatsu T, et al. (2012) Intracellula temperature mapping with a fluorescent polymeric thermometer and fluorescence lifetime imaging microscopy. Nat Commun 3: 705.

25. Carterson AJ, zu Bentrup KH, Ott CM, Clarke MS, Pierson DL, et al. (2005) A549 Lung Epithelial Cells Grown as Three-Dimensional Aggregates: Alternative Tissue Culture Model for Pseudomonas aeruginosa Pathogenesis. Infect Immuno 73: 1129-1140.

26. Karimi-Busheri F, Rasouli-Nia A, Mackey JR, Weinfeld M (2010) Senescence evasion by MCF-7 human breast tumor-initiating cells. Breast Cancer Res 12: R31.

27. McCool DJ, Forstner JF, Forstner GG (1995) Regulated and unregulated pathways for MUC2 mucin secretion in human colonic LS180 adenocarcinoma cells are distinct. Biochem J 312:125-133.

28. She JJ, Zhang PG, Wang X, Che XM, Wang ZM (2012) Side population cells isolated from KATO III human gastric cancer cell line have cancer stem cell-like characteristics. World J Gastroenterol 18: 4610-4617.

29. Kaur A, Gupta U (2012) Simultaneous Spectrophotometric Determianation of Eosin and Erythrosine with $\mathrm{Cr}(\mathrm{VI})$ Reagent in Micellar Media Using Mean Centering of Ratio Spectra. Chem Sci Trans 1: 424-430.

30. Nasef BE, Chen YD, Walker ML, AL-Sheikhly M, Mclaughlin WL (1995) Anionic Triphenylmethane dye solutions for Low-dose food Irradiation Dosimetry. Radiat Phys Chem 46: 4-6.

31. Hesse M, Meier H, Zeeh B (2008) UV/Vis Spectroscopy. In: Spectroscopic Methods in Organic Chemistry (2ndedn.) Thieme, New York.

32. Hosmer DW, Jr., Lemeshow S, Sturdivant RX (2013) The Multiple Logistic Regression Model. In: Applied Logistic Regression (3rdedn.) Wiley, New York. 